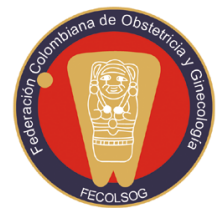

\title{
RESILIENCIA Y COVID 19
}

oy me dirijo a todos mis colegas en calidad de presidente de la Federación Colombiana de Obstetricia y Ginecología (FECOLSOG), a fin de tomar la vocería en estos tiempos difíciles para los equipos de salud, primera línea de atención frente a la pandemia del SARS-COV2, tiempos de inseguridad, temor y cambio. Al ser responsables de la salud de nuestros pacientes nos vemos abocados al tratamiento y manejo de una enfermedad de la cual conocemos poco y enfrentamos en su total magnitud.

Nunca como ahora la humanidad y la sociedad global se habían mostrado tan frágiles ante una amenaza como el COVID 19, causada por un virus de la familia del coronavirus, identificado por primera vez en China en diciembre de 2019, que rápidamente -y a diferencia de otras epidemias como el síndrome respiratorio agudo grave (SARS), el síndrome respiratorio de Oriente Medio (MERS), la influenza, el ébola y el zika- alcanzó un ritmo de contagio y propagación exponenciales. Algunas proyecciones expresan que la mortalidad alcanzará entre el 3 y 14\%, lo que significa de 3 a 150 millones de muertes de seres humanos, muchas más que las originadas por la gripe española de 1918-1919, que mató unos veinte millones de personas en todo el mundo. Asimismo, es probable que sigan otras oleadas del virus de manera recurrente en diferente tiempo y lugar.

Somos testigos del colapso de los sistemas sanitarios de países desarrollados, también llamados de altos ingresos, como Italia, España, Francia, Estados Unidos, Alemania e Inglaterra, que considerábamos modelos de sistemas de salud y seguridad social, y sucumbieron ante las necesidades de infraestructura y personal sanitario ocasionadas por la pandemia. Esta fractura implica un quiebre de los modelos de cuidado y la pérdida de valores humanos. Latinoamérica, con sistemas de salud precarios, varios de ellos apéndices de modelos de la lógica neoliberal, como los casos de Chile y Colombia, con privatización de la salud en esquemas de subsidio a la demanda; otros con esquemas mixtos como Perú, Argentina y Ecuador, con una débil infraestructura sanitaria y de la mano de presidentes con gobernabilidad cuestionada, se ha visto severamente afectada, con tasas de letalidad elevadas.

Nuestro país, con un sistema de salud que expresa la inequidad y desigualdad de nuestra sociedad, y una débil infraestructura hospitalaria, registra 5.300 camas de cuidados intensivos, de las cuales 2.600 están destinadas para atender pacientes afectados por Covid. Sin embargo, departamentos como Guainía, Amazonas, Vichada y Vaupés no cuentan con una sola cama de cuidado intensivo, como expresión de rezagos históricos y del centralismo burocrático; en estas regiones, además, no existen los recursos financieros para pagar las obligaciones laborales en muchos hospitales. El talento humano ha sido subvalorado desde la Ley 100, que ha empobrecido y llevado a la aceptación tácita de condiciones negativas para la prestación de los servicios; más del $80 \%$ de los profesionales no cuentan con las garantías mínimas para desarrollar su labor.

Es en una crisis como la actual, cuando es posible emprender verdaderas reformas al sistema de salud; en 
este contexto, esperamos que la dicotomía del "negocio de la salud" contra "la salud pública" se dirima en favor de esta última. La pandemia del Covid 19 es un problema complejo, que implica para su solución un análisis desde diferentes disciplinas y desde la perspectiva de la salud pública, la economía, la ecología, la bioinformática, entre otros, mediante modelos no lineales que obligan a repensar nuestro estilo de vida y a redefinir nuestras prioridades. El aislamiento y la cuarentena nos han enseñado que no podemos continuar con ese modelo consumista y productivista, se requieren cambios que reduzcan la contaminación y generen beneficios en el medio ambiente. Debemos volver a lo más básico de la convivencia humana, a la familia, los vecinos y amigos más cercanos; a cantar y ejecutar un instrumento en los balcones.
En la Federación Colombiana de Obstetricia y Ginecología, liderada por la Junta Directiva, estaremos en el día a día de la crisis, aportando la fortaleza técnico-científica de sus miembros; proponiendo soluciones colectivas, solidarias y humanas para el bienestar de la mujer colombiana. Igualmente, nos corresponde explorar nuevas oportunidades en la simulación y la big-data, la educación virtual y nuevos esquemas de interacción con la comunidad y los asociados con el máximo aprovechamiento de internet. En pocas palabras, debemos mostrar nuestra resiliencia al Covid 19.

\section{Armando Solano Gámez}

Presidente Fecolsog, 2018-2020. 